\title{
EFFECTS OF THE TECTONIC MOVEMENTS ON THE KARSTIFICATION IN ANATOLIA, TURKEY
}

\section{UČINKI TEKTONSKIH PREMIKANJ NA ZAKRASEVANJE V ANATOLIJI, TURČIJA}

IBRAHIM ATALAY ${ }^{1}$

${ }^{1}$ Department of Geography, Buca Faculty of Education, Dokuz Eylul University, 35150 Buca, Izmir- Turkey, e.mail: ibrahim.atalay@deu.edu.tr 


\section{Abstract}

UDC: $551.44: 551.24(560)$

\section{Ibrahim Atalay: Effects of the tectonic movements on the karstification in Anatolia, Turkey}

Turkey has several types of karstic land-forms containing lapies (karren), caves, dolines, uvalas and poljes. Karstification is related also to the tectonic movements. Well-developed karstic features such as wide poljes, ground water and cave system are widespread in/on the Mesozoic comprehensive limestone in the Taurus Mountains. Karstification begun to develop towards the end of the Mesozoic by the uplift movements of the Taurus Mountains in general. Some large poljes were occupied by the Neogene lakes in which lime and clay accumulated. The fresh water lakes such as Lake Beyşehir and Egirdir are found in the tectonic-karstic depressions. Underground river systems are found between the Lake Region (western Taurus) and Mediterranean coast. These river systems have been shifted towards the deeper parts of the limestone as the result of the progress of karstification and the vertical uplift of the Taurus Mountains (upper Tertiary, Early Quaternary). Caves formed as the result of vertical tectonic movements. These movements caused the lowering of the base level. So the karstification process have shifted from the upper level to deeper parts of the Taurus. Key words: karstification, karstic land-forms, Anatolia.

\section{Izvleček}

UDK: 551.44:551.24(560)

\section{Ibrahim Atalay: Učinki tektonskih premikanj na zakrasevanje v Anatoliji, Turčija}

V Turčiji so razvite različne kraške oblike, škraplje, jame, vrtače, uvale in polja. Zakrasevanje je odvisno tudi od tektonskih premikanj. Dobro razvite kraške oblike, kot velika polja, podzemeljski tokovi in jamski sistemi, so na široko razviti v mezozojskih apnencih v gorovju Taurus. Z dvigom Taurusa konec mezozoika se je na splošno pričelo zakrasevanje. V nekaterih velikih poljih so bila v neogenu jezera, v katerih sta se odlagala apnenec in glina. Sladkovodna jezera, kot Beyșehir in Egirdir, so v tektonsko-kraških depresijah. Sistemi podzemeljskih rek so med jezersko regijo (zahodni Taurus) in sredozemsko obalo. Ti sistemi so se spustili v globlje dele apnenčevega masiva zaradi napredovanja zakrasevanja in dviga Taurusa (zgornji terciar, spodnji kvartar). Jame so nastale kot rezultat teh navpičnih tektonskih premikov, zaradi katerih se je zni•ala erozijska baza. In tako se je proces zakrasevanja prestavil iz višjih v globlje dele Taurusa.

Ključne besede: zakrasevanje, kraške oblike, Anatolija. 


\section{INTRODUCTION}

Karstic areas cover especially the middle and western part of the Taurus Mountain and also occur in the southern parts both of Central Anatolia, the southeastern Anatolian region. and other part of Anatolia (Fig. 1). Karstification and karstic landforms are generally different size and types due to the limestone composition, climate, altitude and geomorphologic evolution (Erinc 1960; Atalay 1987a). In this article the karstification process and main karstic landforms will briefly be explained in terms of tectonic movements.

\section{TECTONIC MOVEMENTS AND GEOMORPHIC EVOLUTION}

Vertical tectonic movements are mainly responsible for karstification and karstic landforms. Indeed most of the formation of deep and large karstic depressions, especially poljes are related to the vertical tectonic movement. That is, large poljes are found within the tectonic basins and/or corridors (Fig. 2).

The development of karstification and karstic landforms in the western part of the Taurus mountains can be summarized according to geological periods.

Mesozoic: The present-day Taurus mountain range areas were occupied by Tethys ocean in which mostly limey material accumulated during the Mesozoic. Towards the end of the Mesozoic, the Taurus range system had started to uplift as the result of the subduction of the Africa plates trough the Mediterranean basin. After most of the Taurus mountain areas had emerged from the sea, karstification process commenced to develop (Fig. 3A).

Tertiary: Karstification process continued during the Eocene and Oligocene except for some subsidence areas. For example, some subsidence areas which are found in the southern part of

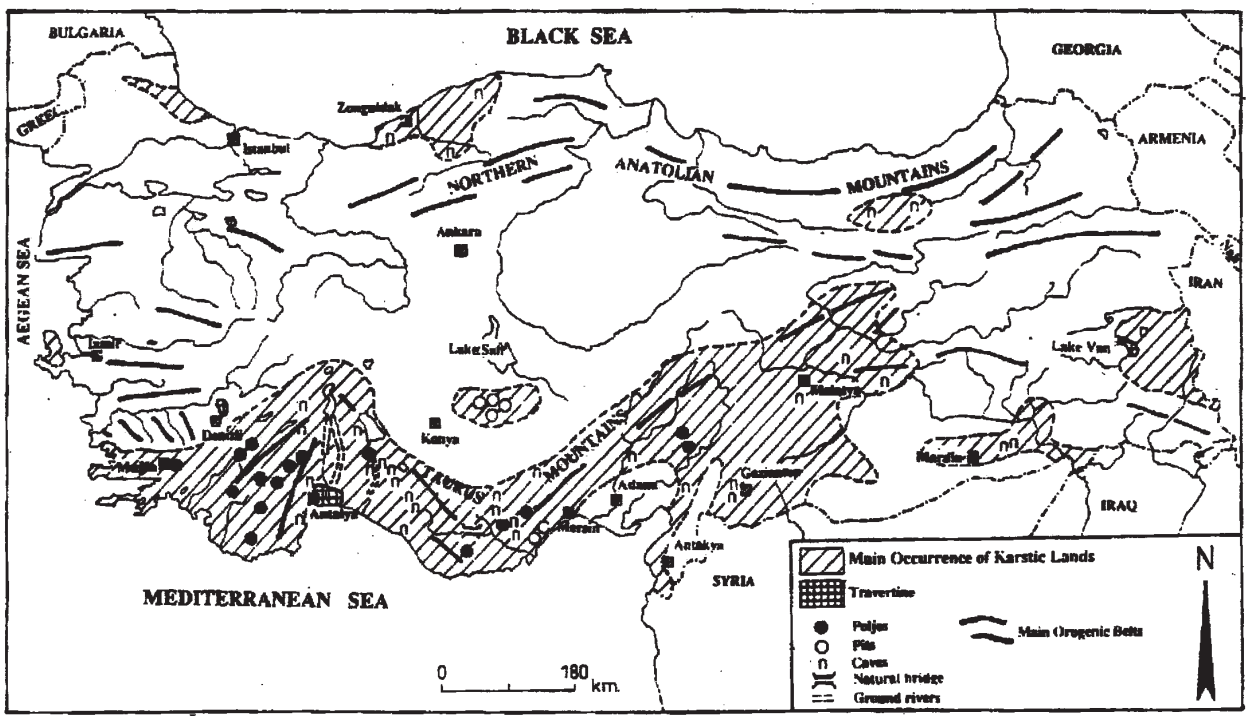

Fig. 1: Principal karstic regions of Turkey (Atalay, 1996). 
Teke peninsula in the W part of the Taurus Mountains were occupied by a shallow Eocene sea (Atalay 1987a; 1987b).

During the Oligocene, the paroxysm phase of the Alpine orogeny occurred so pre-Oligocene outcrops got folded and some limestones were crystallized.

During the Miocene, most of the Taurus mountains were subjected to vertical tectonic movements which are named post-Alpine movements, as in many part of Anatolia. As the result of these vertical movements, tectonic grabens were formed along the fault zones most of which were occupied by the shallow sea and lake. Indeed, the grabens such as Bucak, Beysehir-Seydisehir, Acipayam, etc. were occupied by the lakes in the western part of the Taurus Mountains. In some lake basins the deposits lignite formed. The middle part of the Taurus Mountains was occupied by the Mediterranean Sea in which limly material containing sand and clay were deposited as the result of subsidence events (Atalay 1987a; 1987b; 1988; 1989; 1996).
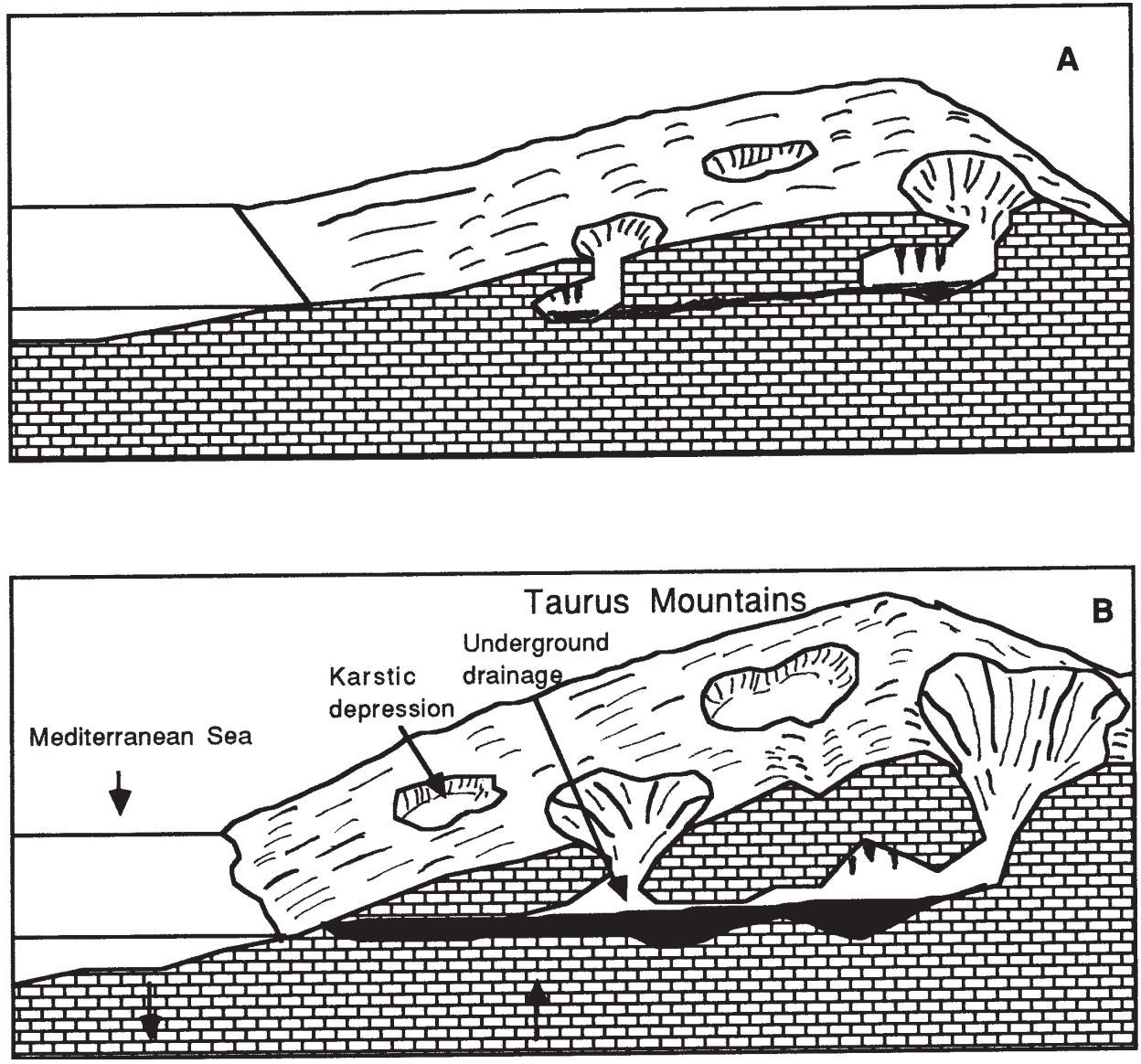

Fig. 2: A) Beginning of the karstification process towards the end of the Mesozoic era, B) Develop and rejuvenation of the karstification process with the uplift of the Taurus Mountains. 

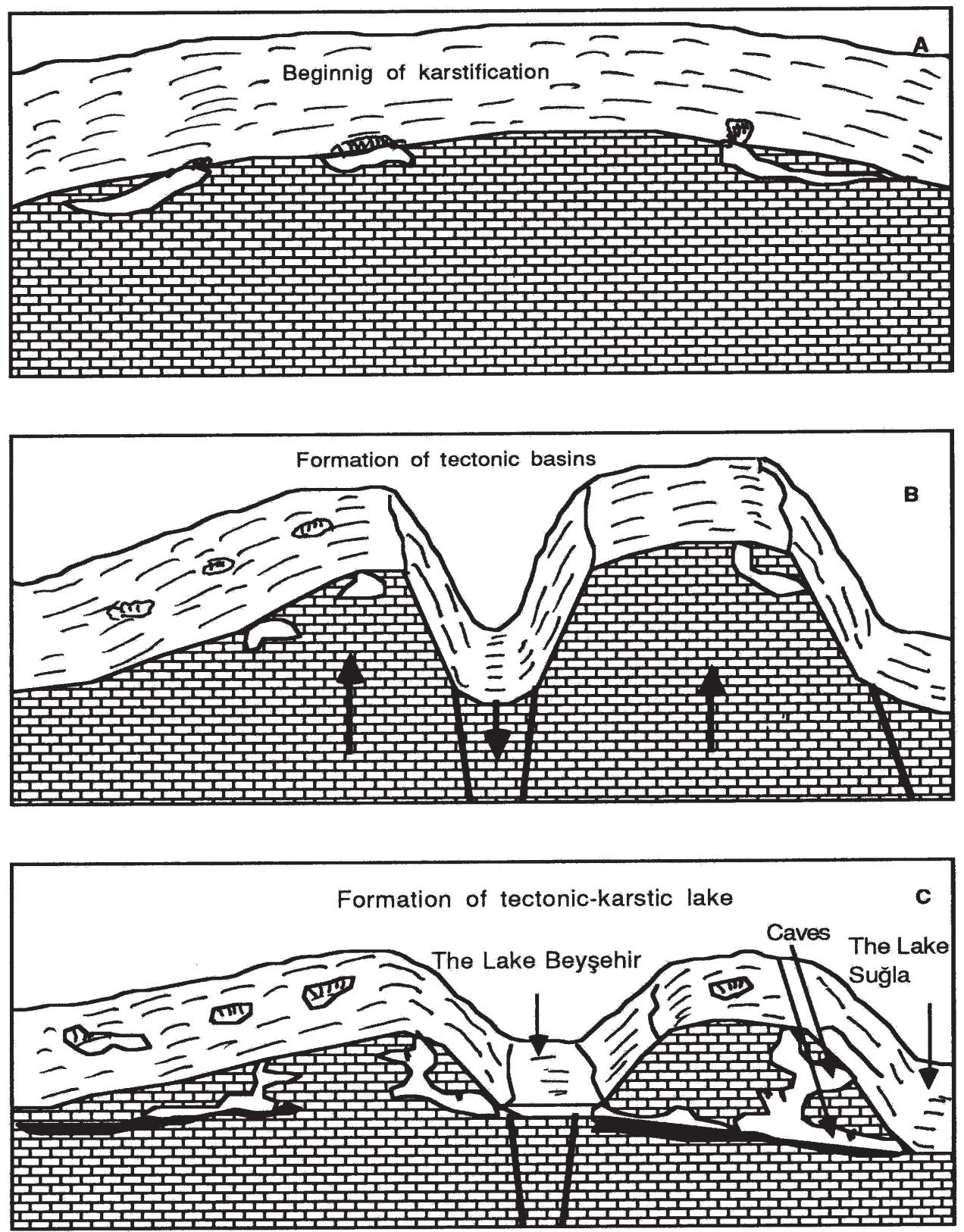

Fig. 3: A) First stages of karstification towards the end of the Mesozoic, B) The formation of tectonic graben by the vertical tectonic movement occurred during the Neogene, C) Increase of karstification process, the formation of cave systems which are found at a different vertical level. 
Towards the end of the Tertiary, the Taurus mountain range had been completely uplifted. The uplift of the Taurus mountains has caused an increase of karstification because of the fact that the base level of the karstic land lowered. Thus water draining off the uplifted areas has begun to dissolve limestone along the crack system and fault lines (Fig. 2, 3B and 3C). The ground water system and caves began to develop. The main poljes have formed, especially along the weak zone fitting fault lines. For this reason main poljes appearing within the grabens such as Bucak, Seki, Celtikci and Sugla formed (Aygen 1984, Guldali 1970; 1973; 1976; Guldali \& Nazik 1984).

The lakes occupying the old poljes have caused the increase of the intense dissolution especially along the weak zone. Thus sinkholes located in the karstic depression have been converted into the ground water system. Some rivers draining off the karstic land shifted and captured towards downward as the result of the uplift of the Taurus. One can see misfit valley and wind gaps in the
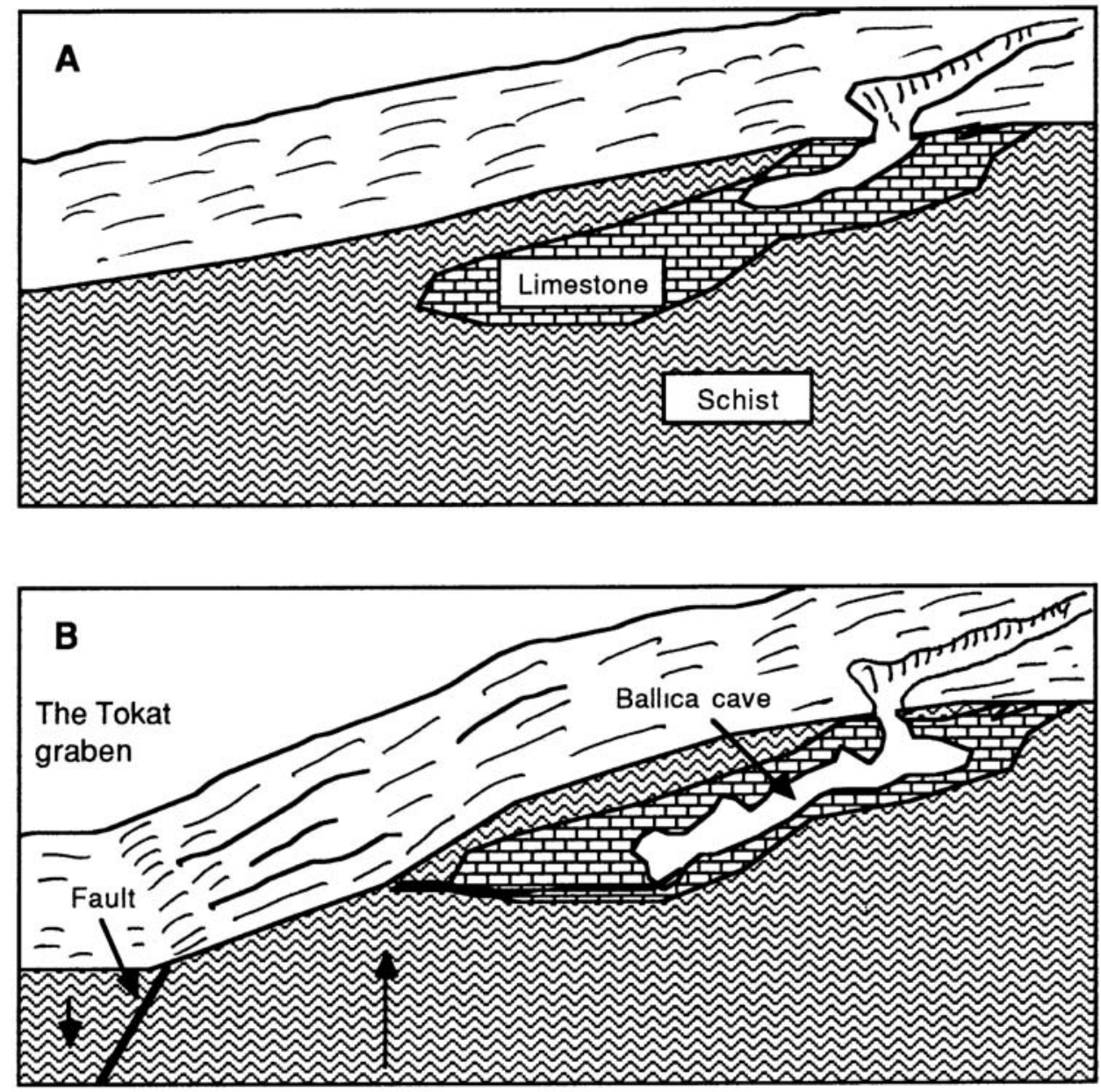

the base level after the formation of Tokat Graben. 
Taurus. In addition to these, there are 3 cave systems developed in the vertical direction within the Upper Craterous limestones in the southern part of the Lake Sugla Polje area. The caves and dried up or wind gaps are found toward the Sugla poljes. The misfit valley indicates that the river was flowing into the Lake Sugla. On the other hand, the surface drainage shifted towards the ground river system as the result of the uplift of the Taurus mountains and so the upper cave systems which are found upper part of this area, remained hanging situation while the lower one continued to develop (Guldali \& Nazik, 1984). Numerous caves which are found in the different altitude appear between on the coastal belt of Mediterranean Sea and Lake region (Aygen 1984) (Fig. 3).

Another prominent cave system is seen in the western part of the Tokat city, in the northern part of Anatolia. The formation of the Ballica Cave, which is located on the southern slopes of Tokat graben, is related to the vertical tectonic movements. Initially the karstification process had commenced in the Paleozoic limestones which are found as a big lens within the Paleozoic schists. A ground water course has started to develop along the fault line cutting the Paleozoic limestones after the Tokat graben had been formed by the vertical movement. Thus the base level of the river course has lowered in the graben area. With the karstification has rejuvenated the ground river which has continued to enlarge. Shortly the formation of the Tokat Graben led to the lowering of the base level and so the Ballica Cave system has developed (Fig. 4).

Another example is also seen in the southern part of Lake Van, Eastern Anatolia. With the uplift of the Taurus Mountains the surface drainage system has shifted deeper. Best examples can be given in the Ihtiyarsahap Mountains, in the southern part of the Lake Van. Here some ground courses feeding from the poljes have been shifted towards the deeper part as the result of the uplift of the mountains. The ground drainages may have continued towards the Lake Van, have been captured and diverted towards the deep valleys. For example, the karstic springs appearing through the Catak and Bahcesaray valley may be related to the diversion of the ground water discharge. The springs along the above mentioned valley feed from the sinkholes within the poljes

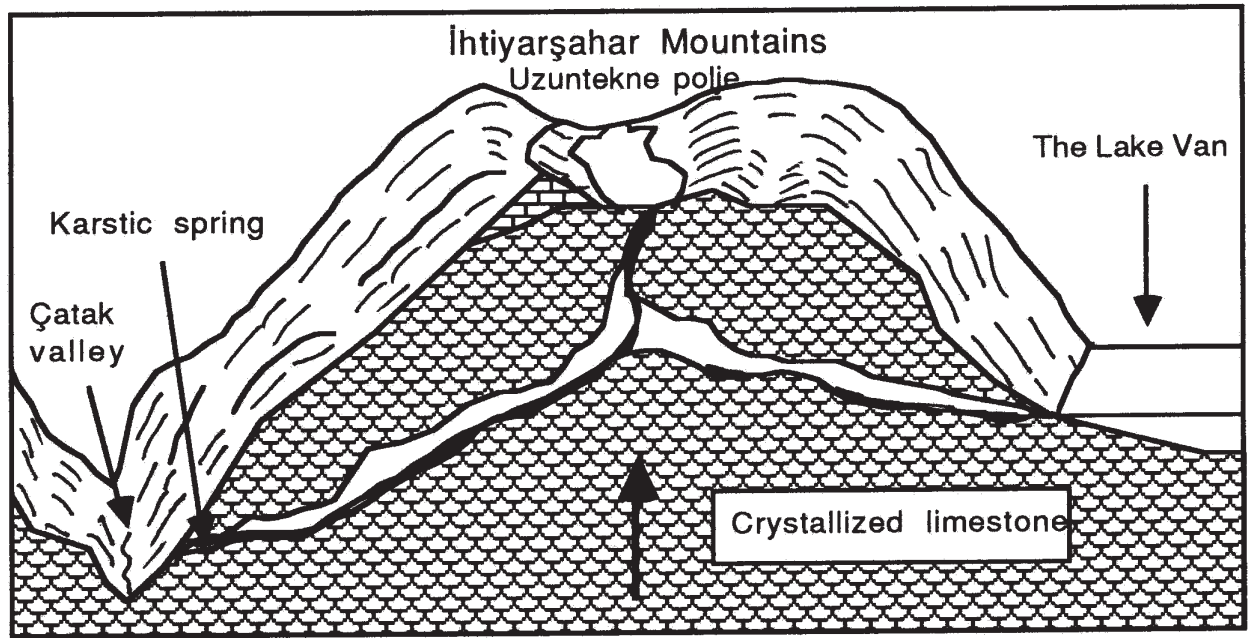

Fig. 5: The formation of the karstic sources along the valley as the shifting of ground water in the southern part of the Lake Van 
which are found on the upper part of the mountains (Fig. 5).

In addition to these, some doline areas have collapsed as the result of dissolve of limestone with the uplift of the Taurus Mountains. The best examples are given in the vicinity of Silifke on the coastal belt of the Mediterranean Sea. In these areas cylindrical dolines or karstic pits called Cennet and Cehennem are found. These sinkholes and caves containing stalagmites and stalactites follow the old dried up valley. The cauldron and some karstic features which are seen along the valley in the SE Anatolia are mostly related to the lowering of the base level of streams (Bilgin 1963).

Uplifting movements have led to the formation of bauxite deposits which are found in the western the Taurus Mountains because the remained clay components as the result of the intense karstification accumulated within the karstic hole.

It can be clearly said that the rich karstic features and the poljes have been formed as the result of vertical tectonic movements.

\section{RESULTS}

The Taurus Mountains having rich karstic formation and forms are mostly related to the results of the successive karstification processes.

1. Most of the poljes are located in the tectonic grabens which were formed post-Alpine vertical tectonic movements. The uplift of the Taurus Mountains has caused the increase of karstification proceses. Different cave systems in the vertical direction testify this.

2. Majority of caves having ground river and ponds occur along the axis bend extending between Antalya-the Mediterranean Sea and the Lake Egirdir. Main fault lines extending south-north direction led to increase of the dissolution process.

\section{REFERENCES}

ATALAY, I, 1973, Some observation on the karstification and soil formation in the Taurus Mountains (Turkish, summary in English): Bull. of Geomorphology, 5: 135-151.

ATALAY, I. 1987a, Introduction to Geomorphology of Turkey (in Turkish). Ege University, Faculty of Letters Pub. Nu: 9, 454 pages, Izmir.

ATALAY, I. 1987b, The ecological conditions of the natural occurrence areas of cedar (Cedrus libani A. Rich.) and regioning of seed transfer of cedar in Turkey. General Dir. of Forest Pub Nu.: 661/63, Ankara, 167 pages.

ATALAY, I. 1988, Karstification and the ecology of the karstic land in the Taurus Mountains (Summary in English), Bull. of Geomorphology, 16: 1-8.

ATALAY, I. 1989, Soil formation of the karstic lands of the Taurus Mountain (in Turkish). Papers of $10^{\text {th }}$ Soil Science Union, Pub Nu. 5: 18.1-3.

ATALAY, I. 1991, Soil formation in the karstic land in Turkey. Proceedings of the International First Regional Conference of Geomorphology, Special Issue, 19, Bulletin of Geomorphology, 19: 139-144.

ATALAY, I., 1995, Pedogenesis and ecology of karstic lands in Turkey. Acta Carsologica, XXIV: 53-67.

ATALAY, I., 1996, Karstification and karstic landforms in Turkey. Karren Landforms (Ed. J. J. 
Fornos and A. Gines). Universidad de les Balears, Spain: 325-334.

AYGEN, T. 1984, Turkish Caves. Pub. of Turkish Turing and Otomobile Society, Istanbul.

BILGIN, T. 1963, The formation of some karstic forms with relating to slope evolution on the plateau areas western part of Gaziantep (in Turkish). Review of Geog. Inst. of Istanbul. 13:164-170.

ERINC, S., 1960, Karstic features in the Konya region and inner part of the Taurus Mountains. Review of Turkish Geog. Society, 20: 83-106.

GÜLDALI, N. 1970, Karstmorphologische Studien im Gebiet des Poljesystem von Kestel (Westlicher the Taurus, Turkei). Tubingen Geog. Studien, 40.

GÜLDALI, N. 1973, Seydisehir and Akseki bauxite deposits and their relation to paleokarst phonemenina in the Tauruss Mountains. Cong. of the Earth Sci. on Occassion the 50th An. of Turkish Rep.,: 391-408.

GÜDALI, N. 1976, Akseki poljes. The formation and evolution of intermontane plain in the karstic lands of the Taurus Mountains (in Turkish). Geol Bull. of Turkish Soc. 19 (2):143148.

GÜLDALI, N. and NAZIK, L.1984, The karstic evolution of Tinaztepe cave system and its immediate surroundings. Bull. of Geomorhology, 13: 107-114.

NAZIK, L. and GULDALI, N. 1985: Incesu caves system (Taskale-Karaman): Geomorphologic evolution and economic possibilities. Bull. of Geomorphology, 13: 47-52.

NAZIK, L., 1986, Karst geomorphology and examine of karstic parameters of near of the Lake Beysehir (in Turkish). Bull. of Geomorphology, 14: 65-78. 